\title{
Assessing the impact of non-native freshwater fishes on native species using relative weight
}

\author{
D. Giannetto ${ }^{(1) \star}$, A. Carosi ${ }^{(1)}$, E. Franchi ${ }^{(1)}$, L. Ghetti ${ }^{(2)}$, G. Pedicillo ${ }^{(1)}$, \\ L. Pompei ${ }^{(1)}$ and M. Lorenzoni ${ }^{(1)}$
}

Received April 20, 2011

Revised October 20, 2011

Accepted October 25, 2011

\section{ABSTRACT}

Key-words: condition indices, alien species, native species, density of species, longitudinal gradient

\begin{abstract}
The aim of the research was to test relative weight $\left(W_{\mathrm{r}}\right)$, a condition index which allows evaluation of fish well-being, as a tool to investigate the impact of the presence of non native species (NNS) on the condition of the key native species (NS) of the Tiber River basin (Italy): Barbus tyberinus Bonaparte, Leuciscus cephalus (Linnaeus), Leuciscus lucumonis Bianco, Rutilus rubilio (Bonaparte) and Telestes muticellus (Bonaparte). By means of Canonical Correlation Analysis, data from 130 sampling sites, distributed throughout Tiber River basin, were examined. $W_{r}$ of NS was related to densities of NNS and to environmental variables. Moreover, the correlation between $W_{r}$ of NS and density of NNS was investigated through linear regression analysis and covariance analysis. Preliminary results encourage the use of $W_{r}$ as a tool to assess the relationship between NS and ecological factors (such as the presence of NNS) and to explain the changes that occur along the longitudinal gradient of a river.
\end{abstract}

\section{RÉSUMÉ}

\section{Évaluation de l'impact des poissons d'eau douce non indigènes sur les espèces indigènes} utilisant le poids relatif

Mots-clés :
indice de
condition,
espèces
exotiques,
espèces
indigènes,
densité des
espèces,
gradient
longitudinal

\begin{abstract}
Le but de cette recherche était de tester le poids relatif $\left(W_{\mathrm{r}}\right)$, un indice de condition qui permet l'évaluation du bien-être des poissons, comme outil pour étudier l'impact de la présence d'espèces non indigènes (NNS) sur l'état des espèces natives clés (NS) du bassin du Tibre (Italie) : Barbus tyberinus Bonaparte, Leuciscus cephalus (Linné), Leuciscus lucumonis Bianco, Rutilus rubilio (Bonaparte) et Telestes muticellus (Bonaparte). Par le biais de l'analyse de corrélation canonique, les données de 130 sites d'échantillonnage, répartis tout au long du bassin de la rivière Tibre, ont été examinés. Le $W_{r}$ des NS a été relié à des densités de NNS et aux variables environnementales. Par ailleurs, la corrélation entre $W_{r}$ des NS et de la densité de NNS a été étudiée par analyse de régression linéaire et analyse de covariance. Les résultats préliminaires incitent à l'utilisation de $W_{r}$ comme un outil pour évaluer la relation entre les NS et les facteurs écologiques (tels que la présence de NNS) et pour expliquer les changements qui se produisent le long du gradient longitudinal d'une rivière.
\end{abstract}

(1) Dipartimento di Biologia Cellulare e Ambientale, Università di Perugia, via Elce di Sotto, 06123 Perugia, Italy (2) Regione dell'Umbria, Servizio Programmazione Forestale, Faunistico-Venatoria ed Economia Montana, Perugia, Italy

*Corresponding author: danielagiannetto@libero.it 


\section{INTRODUCTION}

The introduction of exotic species is one of the most important causes of species endangerment and extinction (Lowe et al., 2000) and it becomes a widespread phenomenon particularly in recent times due to the increase in aquaculture and stocking programs (Cowx, 1997). With regard to the aquatic ecosystems, the introduction of alien freshwater fishes represents one of the greatest threats for biodiversity and for the integrity of native communities (Mack et al., 2000; Byers et al., 2002; Helfman, 2007).

In Italy, the introduction of non native species (NNS) has induced a progressive loss of the zoogeographic identity of native fish communities (Bianco and Ketmaier, 2001). In the Tiber River basin, the streams are being seriously degraded due to the stocking programs that have modified their native fish fauna: of the 47 fish species currently present only 13 are native (Lorenzoni et al., 2006).

Many authors have commented on the difficulty of documenting the specific role of introduced species on native species (NS), particularly in freshwater fish communities (Belkessam et al., 1997; Copp et al., 2010). However, it is widely agreed that the introduction of fish usually has a damaging effect on the receiving aquatic ecosystem and its native fish fauna (Herbold and Moyle, 1986; Holcik, 1991; Elvira, 1995; Bianco and Ketmaier, 2001).

The degree of changes brought by the introduction and acclimatization of a new species in an aquatic ecosystem is changeable (Keith and Allardi, 1997). The pre-existing fish community may be changed greatly as a result of competition for food or other resources (Leveque, 1997), predation (Jackson and Williams, 1980; Leveque, 1997), parasitism or the introduction of pathogenic agents (Dove and Ernst, 1996; Blanc, 1997; Lodge et al., 2000); hybridization and modification of the environment should also be included as possible harmful effects resulting from the introduction of exotic species. Literature regarding the impact of exotic species reports numerous examples of the extinction of native species (Cowx, 1997; Lodge et al., 2000; Mack et al., 2000). Nevertheless, the cause-effect relationship frequently remains hypothetical, given the limited information that is available about the status of native species prior to the introduction (Lorenzoni et al., 2006; Gaygusuz et al., 2007).

Then, to be successful, any strategy to maintain native biodiversity requires a base of information about the spread, ecological effects and control of NNS (Byers et al., 2002).

Monitoring fish well-being can be useful to investigate these kinds of relationships. Anderson and Neumann (1996) suggested the use of fish condition as an inexpensive and easily measured parameter that under given circumstances, can be a robust predictor of the status of fish populations. Plump fish may be indicators of favorable environmental conditions (e.g. habitat conditions, high prey availability), whereas thin fish may indicate less favorable conditions (e.g. competition, scant of food) (Blackwell et al., 2000).

Relative weight $\left(W_{r}\right)$ (Wege and Anderson, 1978) is one of these indices and it enables the evaluation of the well-being of fish by comparing the actual weight of a specimen with the ideal weight of a specimen of the same species and of the same lenght in good physiological condition, i.e. standard weight $\left(W_{\mathrm{s}}\right)$ (Brown and Murphy, 1991). The advantage of the $W_{\mathrm{r}}$ is that it provides a rapid measure of the physiological status of fish (Brown and Murphy, 1991) and it can be an indicator of ecological changes (Blackwell et al., 2000).

The aim of this research was to test relative weight as a tool to investigate the impact of the presence of NNS on the condition of the key native freshwater species of the Tiber River basin: Barbus tyberinus Bonaparte, 1839; Leuciscus cephalus (Linnaeus, 1758), Leuciscus lucumonis Bianco, 1983, Rutilus rubilio (Bonaparte, 1837) and Telestes muticellus (Bonaparte, 1837).

\section{MATERIALS AND METHODS}

\section{> STUDY AREA AND DATA SELECTION}

The area investigated was the portion of the River Tiber basin (Central Italy) located in Umbria region $\left(9413 \mathrm{~km}^{2}\right.$ ) (Figure 1). The River Tiber is the third-longest river in Italy (405 km) and it 


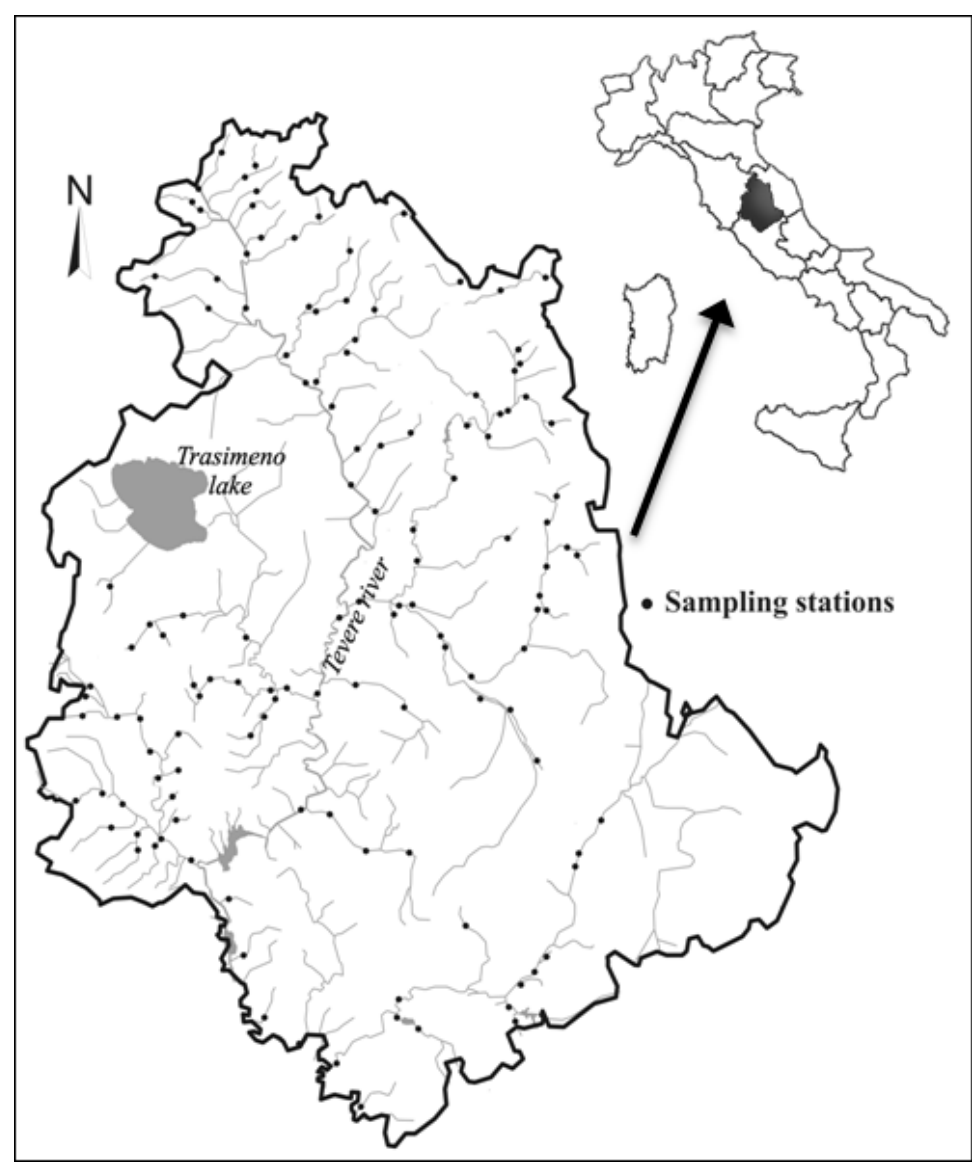

\section{Figure 1}

Study area and location of the sampling sites.

forms the backbone of the hydrological network of Umbria region. Its watershed is the second-largest and it extends into the Italian Regions Umbria, Lazio, Emilia Romagna, Tuscany, Marche, Molise and Abruzzo with a total extension of $17375 \mathrm{~km}^{2}$. Data from 130 sampling sites, collected from 1998 to 2009 in 71 different watercourses, were used for the analysis. Each site was sampled 2 or 3 times for a total of 269 observations. For each station a list of environmental parameters was used to characterize the river sectors (Table I) and a census of the fish fauna was carried out by electro fishing using the removal method (Moran, 1951; Zippin, 1956). The environmental parameters were usually assessed on the same day or within several days of the fish collections. Hydrologic variables were measured at transects within each sampling reach; watershed area, distance from the source, average slope and altitude were determined from topographic maps; field measurements of conductivity, $\mathrm{pH}$, water temperature and dissolved oxygen were made with electronic meters; others chemical parameters of the water were determined according to APHA, AWWA and WPCF (1989) specifications. The Extended Biotic Index (EBI) (Ghetti, 1986), which is a biotic index used to evaluate the overall water quality based on the sensitivity of some key groups of macrobenthic fauna to pollution (Lorenzoni et al., 2006), was assessed on the same day or within several days of the fish collections.

All fish caught were identified and measured for total length, to the nearest $1 \mathrm{~mm}$, and weighted, to nearest $1 \mathrm{~g}$ (Anderson and Neumann, 1996).

Among all fish, five indigenous species, characterizing the fish communities of the "barbel zone" (Mearelli et al., 1995), which is the most represented in Umbria waterways (Lorenzoni et al., 2006), were chosen to analyze the effect of the NNS on the indigenous fauna: $B$. tyberinus; $L$. cephalus, L. lucumonis, R. rubilio and T. muticellus. For these species the density in each 


\section{Table I}

Canonical and correlations coefficients of the environmental parameters and densities of NNS with axis 1 and 2 of Canonical Correspondence Analysis (CCA) (in bold value of $p<0.05)$.

\begin{tabular}{|c|c|c|c|c|c|c|c|}
\hline & \multicolumn{2}{|c|}{$\begin{array}{l}\text { Canonical } \\
\text { coefficients }\end{array}$} & \multicolumn{4}{|c|}{ Correlations with axes } \\
\hline & & $\mathrm{AX} 1$ & $A \times 2$ & $A X 1$ & $p$ & $\mathrm{AX2}$ & $p$ \\
\hline \multirow{24}{*}{ 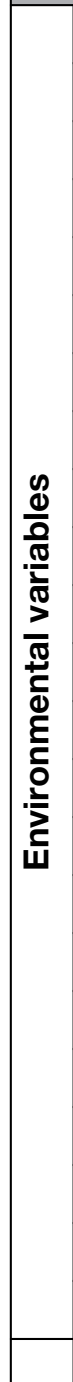 } & Distance from the source $(\mathrm{km})$ & 0.056 & -0.064 & 0.194 & 0.006 & 0.088 & 0.220 \\
\hline & Watershed area $\left(\mathrm{km}^{2}\right)$ & 0.184 & 0.514 & 0.199 & 0.005 & 0.114 & 0.111 \\
\hline & Altitude (m a.s.l) & -0.566 & 0.214 & -0.433 & 0.000 & 0.087 & 0.223 \\
\hline & Average slope (\%) & 0.010 & 0.051 & -0.143 & 0.046 & 0.017 & 0.813 \\
\hline & $\mathrm{pH}$ & 0.110 & -0.052 & -0.022 & 0.764 & -0.073 & 0.311 \\
\hline & Conductivity $\left(\mu \mathrm{S} \cdot \mathrm{s}^{-1}\right.$ at $\left.25^{\circ} \mathrm{C}\right)$ & 0.479 & -0.777 & 0.380 & 0.001 & -0.147 & 0.039 \\
\hline & Nitrate $\left(\mathrm{mg} \cdot \mathrm{L}^{-1}\right.$ as $\left.\mathrm{N}\right)$ & 0.083 & -0.130 & 0.321 & 0.001 & -0.178 & 0.013 \\
\hline & Nitrite $\left(\mathrm{mg} \cdot \mathrm{L}^{-1}\right.$ as $\left.\mathrm{N}\right)$ & 0.149 & -0.110 & 0.223 & 0.002 & -0.078 & 0.277 \\
\hline & Ammonia $\left(\mathrm{mg} \cdot \mathrm{L}^{-1}\right.$ as $\left.\mathrm{N}\right)$ & -0.070 & 0.636 & 0.123 & 0.085 & -0.029 & 0.682 \\
\hline & Sulphates $\left(\mathrm{mg} \cdot \mathrm{L}^{-1}\right.$ as $\left.\mathrm{S}\right)$ & 0.020 & -0.052 & 0.234 & 0.001 & 0.029 & 0.687 \\
\hline & Chlorides $\left(\mathrm{mg} \cdot \mathrm{L}^{-1}\right.$ as $\left.\mathrm{Cl}\right)$ & -0.004 & 0.125 & 0.276 & 0.001 & -0.090 & 0.209 \\
\hline & Water temperature $\left({ }^{\circ} \mathrm{C}\right)$ & -0.014 & 0.008 & 0.174 & 0.015 & 0.002 & 0.980 \\
\hline & Dissolved oxigen $\left(\mathrm{mg} \cdot \mathrm{L}^{-1}\right)$ & -0.106 & -0.077 & -0.121 & 0.091 & 0.032 & 0.652 \\
\hline & Dissolved oxigen (\%) & 0.166 & 0.498 & -0.042 & 0.561 & -0.002 & 0.979 \\
\hline & Extended Biotic Index (E.B.I) & 0.111 & 0.024 & -0.298 & 0.001 & -0.044 & 0.541 \\
\hline & Mean width (m) & 0.044 & 0.037 & 0.124 & 0.083 & 0.145 & 0.042 \\
\hline & Mean depth $(\mathrm{m})$ & -0.414 & -0.032 & 0.095 & 0.185 & 0.012 & 0.867 \\
\hline & Current speed $\left(\mathrm{m} \cdot \mathrm{s}^{-1}\right)$ & 0.167 & -0.522 & -0.105 & 0.143 & 0.135 & 0.059 \\
\hline & Flow rate $\left(\mathrm{m}^{3} \cdot \mathrm{s}^{-1}\right)$ & 0.009 & -0.078 & -0.086 & 0.229 & 0.077 & 0.281 \\
\hline & Wetted river section $\left(\mathrm{m}^{2}\right)$ & -0.153 & 0.168 & 0.068 & 0.342 & 0.097 & 0.175 \\
\hline & Canopy cover (index 0-4) & -0.002 & -0.104 & -0.158 & 0.027 & -0.021 & 0.769 \\
\hline & Instream cover (index 0-4) & 0.245 & -0.476 & -0.057 & 0.427 & 0.092 & 0.200 \\
\hline & Cover plant (index 0-4) & 0.056 & -0.064 & 0.090 & 0.209 & -0.045 & 0.528 \\
\hline & Substrate size (index 0-7) & 0.184 & 0.514 & 0.003 & 0.969 & -0.072 & 0.313 \\
\hline \multirow{10}{*}{ 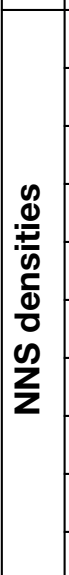 } & A. alborella & 0.092 & -0.021 & 0.202 & 0.001 & 0.033 & 0.589 \\
\hline & B. barbus & 0.035 & 0.078 & 0.165 & 0.007 & 0.148 & 0.015 \\
\hline & C. auratus & -0.287 & 0.241 & 0.150 & 0.014 & 0.117 & 0.055 \\
\hline & P. genei & 0.024 & -0.216 & 0.157 & 0.010 & -0.007 & 0.904 \\
\hline & C. carpio & 0.529 & 0.120 & 0.100 & 0.103 & 0.100 & 0.101 \\
\hline & G. gobio & 0.007 & 0.064 & 0.081 & 0.183 & 0.051 & 0.407 \\
\hline & A. melas & 0.019 & 0.013 & 0.096 & 0.116 & 0.019 & 0.756 \\
\hline & L. gibbosus & -0.215 & -0.116 & 0.056 & 0.358 & 0.084 & 0.171 \\
\hline & P. bonelli & 0.091 & -0.214 & 0.025 & 0.679 & -0.064 & 0.298 \\
\hline & P. parva & -0.042 & 0.273 & 0.100 & 0.102 & 0.116 & 0.057 \\
\hline
\end{tabular}


sample sites was calculated $\left(\mathrm{n}^{\circ}\right.$ specimens $\left.\mathrm{m}^{-2}\right)$ and the condition was evaluated by means of $W_{r}$, on the basis of the equation $W_{r}=100 W / W_{s}$ where $W$ is the weight of the individual and $W_{\mathrm{s}}$ is the standard weight calculated by the standard weight equations proposed for each species for the Tiber River basin (Angeli et al., 2010; Giannetto et al., 2011). In each sample site, the density of all NNS was also calculated and among all, the NNS which proved the most common and which displayed the highest densities in the study area were chosen. By this way 10 NNS were selected: Alburnus alburnus alborella (De Filippi, 1844), Ameiurus melas (Rafinesque, 1820), Barbus barbus Linnaeus, 1758, Carassius auratus (Linnaeus, 1758), Cyprinus carpio Linnaeus, 1758, Gobio gobio (Linnaeus, 1758), Lepomis gibbosus (Linnaeus, 1758), Padogobius bonelli (Bonaparte, 1846), Protochondrostoma genei (Bonaparte, 1839), Pseudorasbora parva (Schlegel, 1846).

\section{> STATISTICAL ANALYSIS}

Mean $W_{r}$ value and densities of the five indigenous species were related to the abundance of NNS and to the environmental parameters by means of canonical correspondence analysis (CCA) (ter Braak, 1986) that is a direct gradient analysis method that allows the examination of the relationships among multivariate ecological data matrices (ter Braak, 1986). Statistical significance was tested with Monte Carlo permutation tests (999 permutations); an axis was considered statistically significant if the eigenvalue from the randomly permuted set exceeded the original in 50 or fewer cases $(p=0.05)$. The fish matrix included $W_{r}, N S$ densities and 269 observations (sampling stations). The environmental matrix included 34 variables (environmental parameters and NNS densities) and 269 observations (Table I). All variables $(N)$ were transformed $(\ln (N+1))$ and standardized (Brown and Austen, 1996).

To evaluate the relationship between $W_{r}$ and density of NS, the regression with the axis 1 of CCA was examined through linear regression analysis (GLM) by means of normal distribution (Maunder and Punt, 2004).

Two different approaches were used to investigate the impact of NNS on $W_{r}$ of NS. First, relationship between $W_{r}$ of every NS and density of each of NNS was analyzed through linear regression (GLM) analysis and the slopes in these relationships were evaluated to examine the trend of changes in $W_{r}$ values with the increasing of NNS density. Second, the covariance analysis (ANCOVA) was applied to all the relationships showing a statistically significant negative slope according to GLM analysis. Mean $W_{r}$ values of NS under condition of absence and presence of each of NNS were compared; to eliminate the potential effect of longitudinal gradient (which could mask the impact of NNS on condition of NS), the axis 1 of CCA (which should represent the longitudinal gradient) was used as a covariate.

\section{RESULTS}

The first axis of the CCA explained $68.7 \%$ of the overall variability (Table II). Analyzing the canonical and correlation coefficients of the environmental variables with axes of CCA (Table I and Figure $2 \mathrm{a}$ ), it resulted that most of these variables were significantly correlated with the

\section{Table II}

Summary statistics for Canonical Correspondence Analysis (CCA): eigenvalues of axes 1 and 2 expressed as percentage of total variance.

\begin{tabular}{|l|c|c|}
\hline & Axis 1 & Axis 2 \\
\hline Eigenvalues & 0.104 & 0.028 \\
\hline Species - environment correlations & 0.643 & 0.457 \\
\hline Cumulative percentage variance of species data & 18.8 & 23.9 \\
\hline Cumulative percentage variance of species-environment relation & 68.7 & 87.3 \\
\hline
\end{tabular}



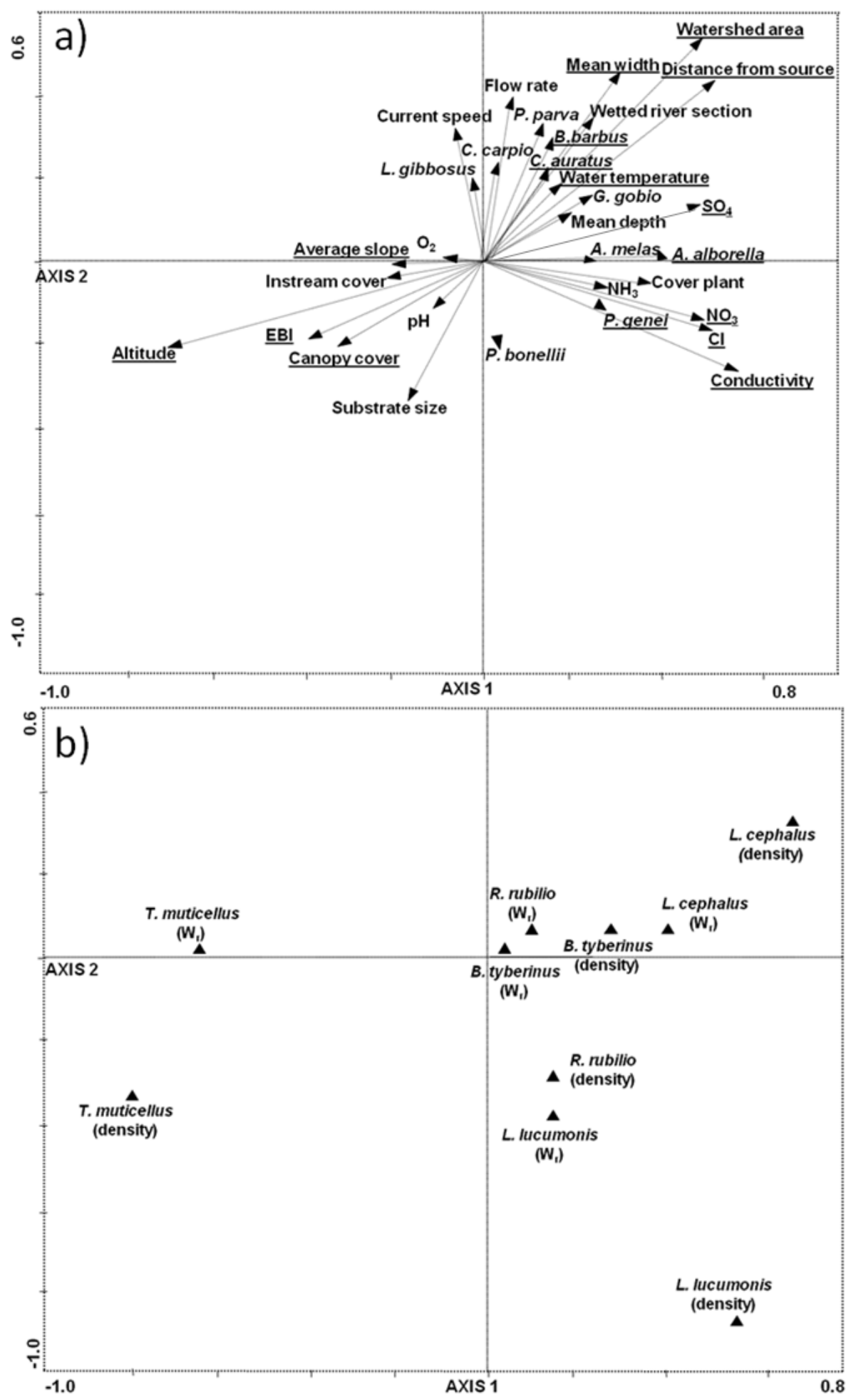

\section{Figure 2}

Canonical Correspondence Analysis (CCA): (a) plot of the environmental matrix showing environmental variables and densities of non native species; (b) plot of the fish matrix with densities and relative weight of the indigenous species. The length of the arrow is proportional to the rate of change: a long arrow indicates that change is strongly correlated with the ordination axes. The underlines variables are those resulted statistically significant correlated with axis 1 . 

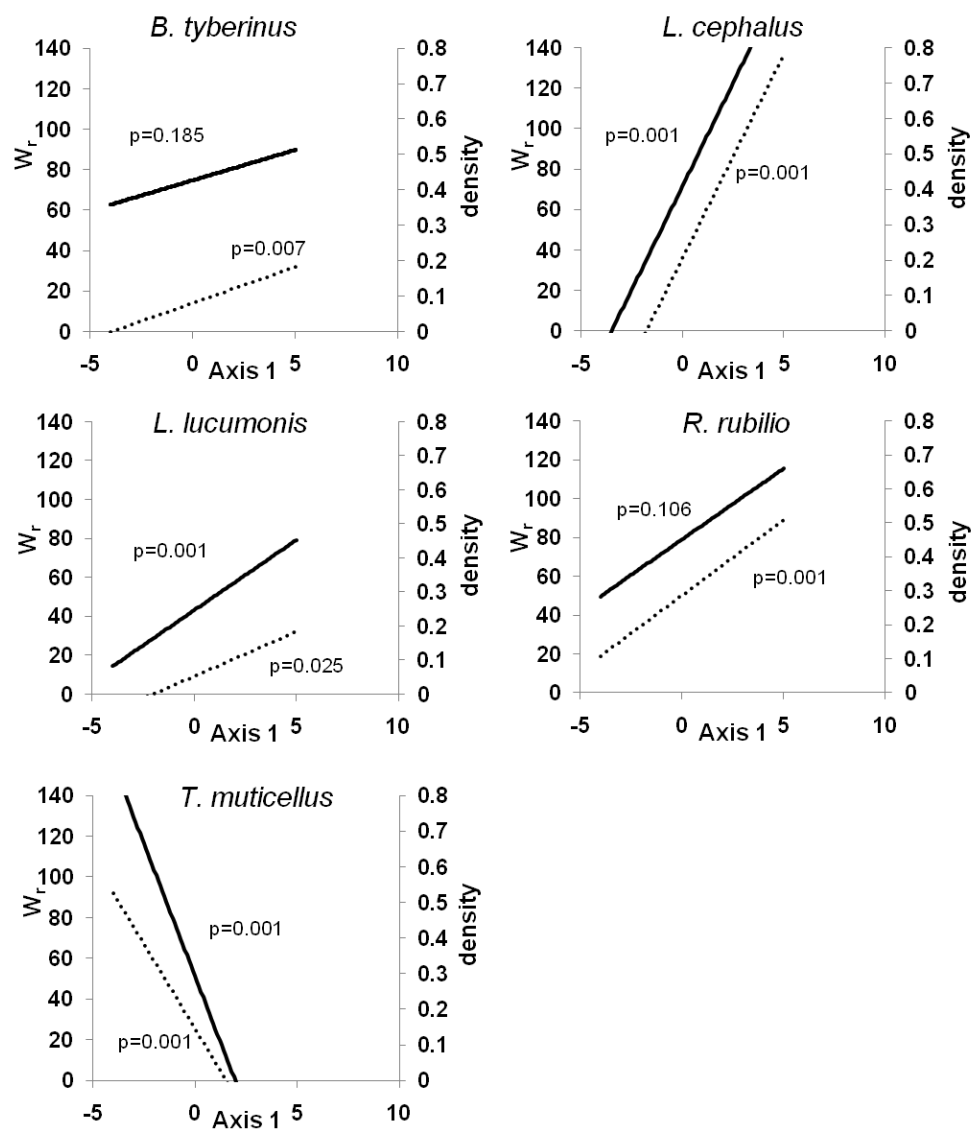

\section{Figure 3}

Relationship between density and relative weight $\left(W_{r}\right)$ on axis 1 of CCA for each of the indigenous species. For each species the solid lines indicate the Wr while the dotted lines are the density.

first axis that well describes the changes that occur along the longitudinal gradient. Specifically, a progressive decline in water quality (EBI, nitrate, nitrite, sulphates, and chlorides) seems to be associated with an increase in river size (distance from the source, watershed area) and water temperature, but also with a decrease in altitude and average slope. In addition the densities of some of the NNS (A. alborella, B. barbus, C. auratus, $P$. genei) resulted to be significantly correlated with axis 1 (Table I and Figure 2a). The second axis of CCA was much less informative (18.6\% of the overall variability) (Table II) and it reflected only the inverse correlation between conductivity and nitrate with density of $B$. barbus and mean width of the watercourses (Table I and Figure 2a). These results reflect the degree of dilution of minerals salts along the river and also the preference of $B$. barbus for large watercourses.

Both the eigenvalues of the first canonical axis and traces (the sum of all eigenvalues) of all canonical axes were significant at the Monte Carlo test $(p<0.01)$ and this emphasizes the strong association among environmental variables and fish variables (NS densities and $W_{r}$ ) (ter Braak, 1986).

The preferred position of the NS along the longitudinal gradient was illustrated by the CCA plot (Figure 2b), in which is showed as the positions of $W_{r}$ and density related to axes were very near for each of the NS. Moreover the regression between $W_{r}$ and density of NS with axis 1 showed that their trends were very similar for all species (Figure 3).

Results of the GLM analysis were summarized in Table III: a significant negative slope between $W_{\mathrm{r}}$ and density of NNS emerged for T. muticellus, $B$. tyberinus and $R$. rubilio against density of NNS. 


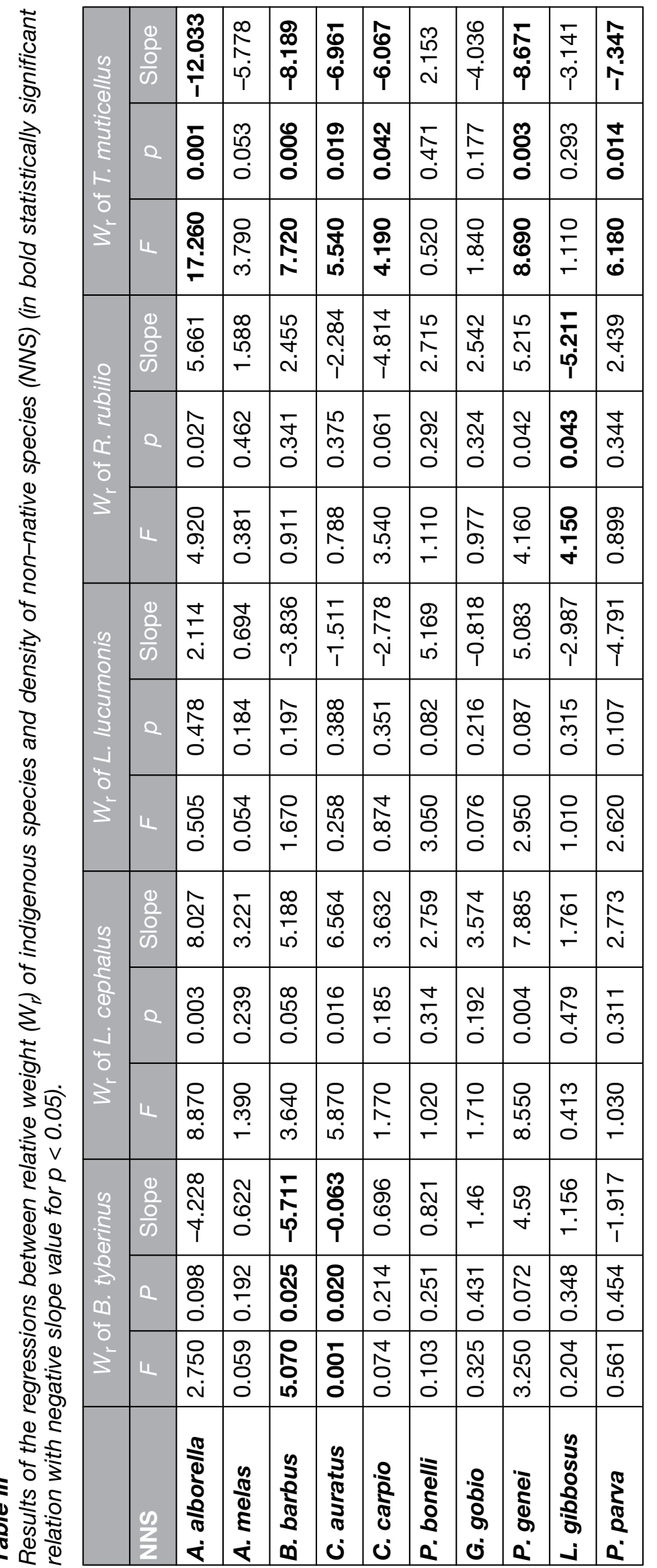




\section{Table IV}

Results of the covariance analysis (ANCOVA) (NS = native species; $N N S=$ non native species; $W_{r}$ absence of NNS = mean value of relative weight in absence of the NNS; $W_{r}$ presence of NNS = mean value of relative weight in presence of the NNS; $p$ and $F=$ values of the covariance analysis).

\begin{tabular}{|l|c|c|c|c|c|}
\hline \multicolumn{2}{|c|}{} & \multicolumn{3}{|c|}{$W_{r}$} & \multicolumn{2}{c|}{} \\
\hline NS & NNS & Absence of NNS & Presence of NNS & $p$ & $F$ \\
\hline \multirow{4}{*}{ T. muticellus } & B. barbus & 97.661 & 93.390 & $<0.001$ & 254.38 \\
\cline { 2 - 6 } & A. alborella & 97.153 & 93.217 & $<0.001$ & 177.86 \\
\cline { 2 - 6 } & B. barbus & 96.987 & 89.241 & $<0.001$ & 130.60 \\
\cline { 2 - 6 } & C. auratus & 97.232 & 93.321 & $<0.001$ & 108.72 \\
\cline { 2 - 6 } & P. genei & 97.100 & 92.300 & $<0.001$ & 99.670 \\
\cline { 2 - 6 } & P. parva & 97.153 & 87.021 & $<0.001$ & 232.89 \\
\hline
\end{tabular}

Table IV and Figure 4 showed the results of the ANCOVA applied to those relationships showing a significant negative slope on GLM analysis: the mean $W_{r}$ value of $T$. muticellus resulted lower in presence of the NNS and the $W_{r}$ of $B$. tyberinus was lower in presence of B. barbus.

\section{DISCUSSION}

In the present study, the use of relative weight to assess the impact of the presence of NNS on the condition of the key NS freshwater species of the Tiber River basin was tested. On the basis of the results, T. muticellus resulted the most sensitive species to the presence of NNS and its condition got worse in presence of $A$. alborella, B. barbus, C. auratus, $P$. genei and $P$. parva; moreover the presence of the NNS $B$. barbus was associated with a decrease in the condition of the native $B$. tyberinus. These results agree with the evidences of other studies conducted in Central Italy: Bianco and Ketmaier (2001) reported that the introduction of $P$. genei in Ombrone river was one of the causes of the decrement in the abundances of T. muticellus and R. rubilio. Carosi et al. (2006) found that in the Tiber River basin the condition of $B$. tyberinus analyzed by means of Fulton condition index (Fulton, 1911) was worse in presence of $B$. barbus, hypothesizing the possibility of a negative competition between these two species.

Nevertheless, some of the results of the GLM analysis (i.e. significant negative trend of $W_{\mathrm{r}}$ of $R$. rubilio against density of $L$. gibbosus) were not confirmed by ANCOVA. Certainly, this kind of correlation did not mean that the two variables ( $W_{r}$ of NS and density of NNS) were related by a cause-effect relationship, but probably they were influenced by other factors or by their interrelation (Meffe, 1984; Harvey, 1991; Godinho and Ferreira, 2000). Hence, considering that in ANCOVA, mean $W_{r}$ of NS in absence and presence of the NNS were compared assuming the same environmental characteristics (using axis 1 of CCA as a covariate), it was possible to suppose that, in these cases, the worsening in the condition should be ascribed to the changes that occur along the longitudinal gradient and not directly to the presence of the NNS.

Another important result of the present study was that $W_{r}$ and density of the NS showed the same trend if related to the changes that occur along the longitudinal gradient. Further researches are required to corroborate the evidence that in lotic environment $W_{r}$ is not affected by density-dependent factors in contrast with the evidences reported by Johnson et al. (1992) for lotic waters. This result could confirm the great importance that abiotic variables 

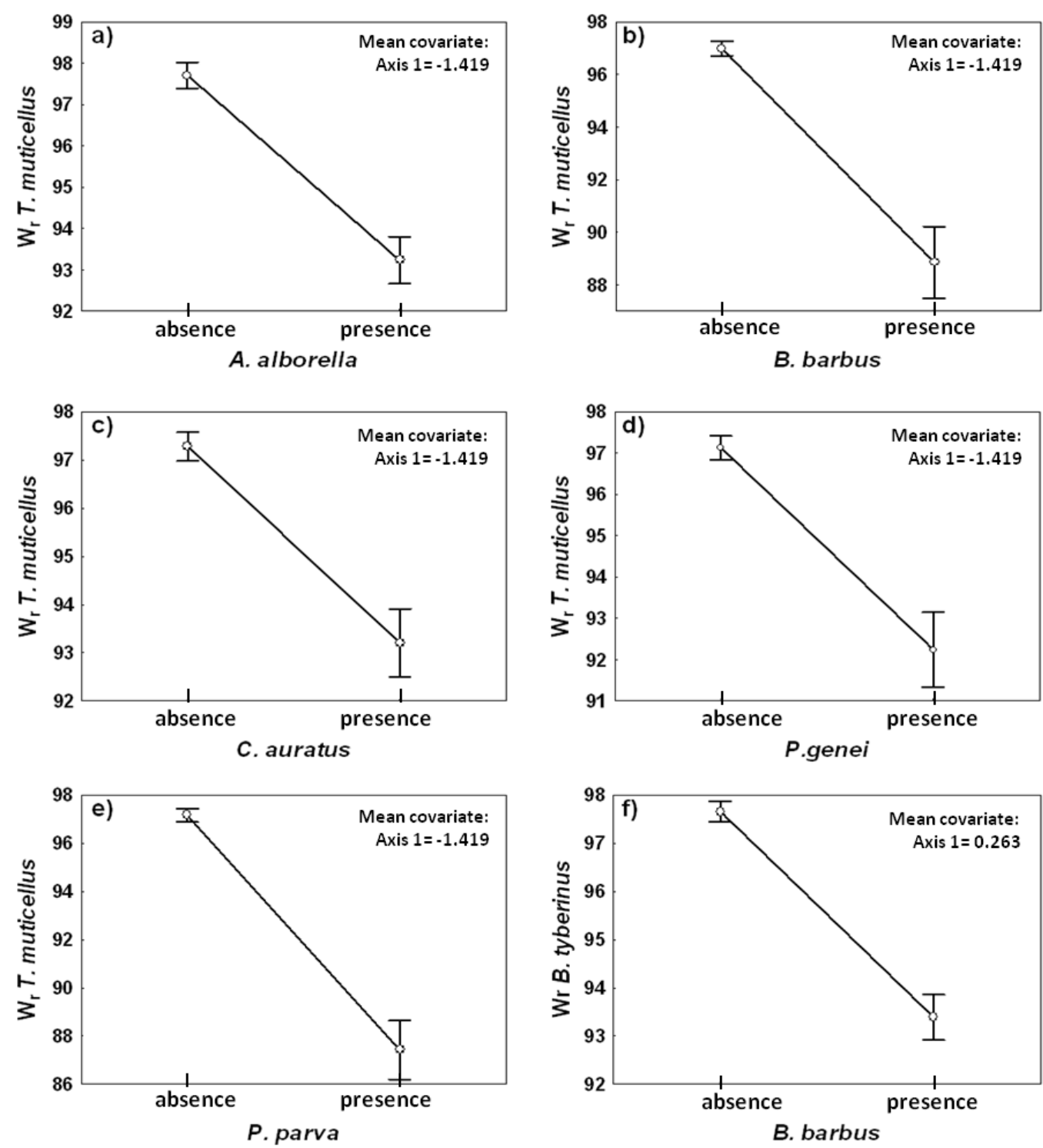

\section{Figure 4}

Results of ANCOVA: differences between $W_{r}$ values of the indigenous species in absence (absence) and presence (copresence) of the NNS for the relationships that, according to the GLM analysis, showed a statistically significant negative slope.

assume in the lotic environments (Blackwell et al., 2000) and in the assemblage of their native fish community (Godinho and Ferreira, 2000). Moreover it could encourage the use of $W_{r}$ as an alternative to density with the great advantage that $W_{r}$ is easier to calculate than density. At the same time, it was important to underline that the use of $W_{r}$ is limited by the need of species-specific standard weight equations that, to be calculated, require a larger data sets from each size classes and that are restricted to a suitable length-range of application (Giannetto et al., 2011).

On the basis of the results of present study, the use of $W_{r}$ to assess the relationship between species and ecological factors (such the presence of NNS) was encouraged. Nevertheless, although the present results appeared to have ecological significance, they should be viewed with caution and, therefore, this approach should be regarded as a preliminary tentative requiring further field experimentation and verification. 


\section{REFERENCES}

Anderson R.O. and Neumann R.M., 1996. Length, weight and associated structural indices. In: Murphy B.R. and Willis D.W. (eds.), Fisheries Techniques, American Fisheries Society, Bethesda, 447-482.

Angeli V., Bicchi A., Carosi A., Spigonardi M.P., Pedicillo G. and Lorenzoni M., 2010. Calcolo del peso standard $\left(W_{\mathrm{s}}\right)$ per le principali specie ittiche del bacino del fiume Tevere. Studi Trentini Di Scienze Naturali, 87, 141-143.

Belkessam D., Oberdorff T. and Hugueny B., 1997. Unsaturated fish assemblages in rivers of northwestern France: potential consequences for species introductions. Bull. Fr. Pêche Piscic., 344345, 193-204.

Bianco P.G. and Ketmaier V., 2001. Anthropogenic changes in the freshwater fish fauna of Italy, with reference to the central region and Barbus graellsii, a newly established alien species of Iberian origin. J. Fish Biol., 59A, 190-208.

Blackwell B.G., Brown M.L. and Willis D.W., 2000. Relative weight $\left(W_{r}\right)$ status and current use in fisheries assessment and management. Res. Fish. Sci., 81, 1-44.

Blanc G., 1997. L'introdution des agents pathogènes dans les écosystèmes aquatiques : aspects théoriques et réalités. Bull. Fr. Pêche Piscic., 344-345, 489-514.

Brown M.L. and Austen D.J., 1996. Data management and statistical techniques. In: Murphy B.R. and Willis D.W. (eds.), Fisheries Techniques, American Fisheries Society, Bethesda.

Brown M.L. and Murphy B.R., 1991. Relationship of relative weight $\left(W_{r}\right)$ to proximate composition of juvenile striped bass and hybrid striped bass. Trans. Am. Fish. Soc., 120, 509-518.

Byers J.E., Reichard S., Randall J.M., Parker I.M., Smith C.S., Lonsdale W.M., Atkinson I.A.E., Seastedt T.R., Williamson M., Chornesky E. and Hayes D., 2002. Directing research to reduce the impacts of non indigenous species. Conserv. Biol., 16, 630-640.

Carosi A., Pedicillo G., Bicchi A., Angeli V., Lorenzoni M. and Ghetti L., 2006. Distribuzione e abbondanza di Barbus barbus (Linnaeus, 1758) nel bacino del fiume Tevere in Umbria. Quaderni ETP J. Freshw. Biol., 34.

Copp G.H., Tarkan A.S., Godard M.J., Edmonds N.J. and Wesley K.J., 2010. Preliminary assessment of feral goldfish impacts on ponds, with particular reference to native crucian carp. Aquatic Invasions, 5, 413-422.

Cowx I.G., 1997. L'introduction d'espèces de poissons dans les eaux douces européennes : succès économiques ou désastres écologiques ? Bull. Fr. Pêche Piscic., 344-345, 57-77.

Dove A.D.M. and Ernst I., 1996. Concurrent invaders four exotic 336 species of Monogenea now established on exotic freshwater fishes in Australia. Int. J. Parasitol., 17, 175-176.

Elvira B., 1995. Native and exotic freshwater fishes in Spanish river basins. Freshwat. Biol., 33, $103-108$.

Fulton T.W., 1911. In: Blackwood W. (ed.), The sovereignty of the sea: an historical account of the claims of England to the dominion of the British seas, and of the evolution of the territorial waters, Edinburgh, London.

Gaygusuz Ö., Tarkan A.S. and Gürsoy Gaygusuz Ç., 2007. Changes in the fish community of the Ömerli reservoir (Turkey) following the introduction of non-native gibel carp Carassius gibelio (Bloch, 1782) and other human impacts. Aquat. Invas., 2, 117-120.

Ghetti P.F., 1986. In: Bertelli (ed.), I macroinvertebrati nell'analisi di qualità dei corsi d'acqua, Trento.

Giannetto D., Carosi A., Franchi E., Pedicillo G., Pompei L. and Lorenzoni M., 2011. Proposed standard weight $\left(W_{\mathrm{s}}\right)$ equations for Telestes muticellus (Bonaparte, 1837) in the River Tiber basin. Cybium., 35, 141-147.

Godinho F.N. and Ferreira M.T., 2000. Composition of endemic fish assemblages in relation to exotic species and river regulation in a temperate stream. Biol. Invasions, 2, 231-244.

Harvey B.C., 1991. Interactions among stream fishes: predator induced habitat shifts and larval survival. Oecologia, 87, 29-36.

Helfman G.S., 2007. Fish Conservation: A Guide to Understanding and Restoring Global Aquatic Biodiversity and Fishery Resources. In: Island Press (ed.), Washington, DC.

Herbold B. and Moyle P.B., 1986. Introduced species and vacant niches. Am. Nat., 128, 751-760.

Holcik J., 1991. Fish introductions in Europe with particular reference to its central and eastern part. Can. J. Fish. Aquat. Sci., 48, 13-23.

Jackson P.D. and Williams W.D., 1980. Effects of brown trout, Salmo trutta L., on the distribution of some native fishes in three areas of southern Victoria. Aust. J. Mar. Freshwat. Res., 31, 61-67.

Johnson S.L., Rahel F.J. and Hubert W.A., 1992. Factors influencing the size structure of brook trout populations in beaver ponds in Wyoming. North Am. J. Fish. Manag., 12,118-124. 
Keith P. and Allardi J., 1997. Bilan des introductions de poissons d'eau douce en France. Bull. Fr. Pêche Piscic., 344-345, 181-191.

Leveque C., 1997. Introductions de nouvelles espèces de poissons dans les eaux douces tropicales : objectifs et conséquences. Bull. Fr. Pêche Piscic., 344-345, 79-91.

Lodge D.M., Taylor C.A., Holdich D.M. and Skurdal J., 2000. Non indigenous crayfish threaten North American freshwater biodiversity: lessons from Europe. Fisheries, 25, 7-20.

Lorenzoni M., Ghetti L. and Mearelli M., 2006. Native and exotic fish species in the Tiber River watershed (Umbria - Italy) and their relationship to the longitudinal gradient. Bull. Fr. Pêche Piscic., 382,19-44.

Lowe S., Browne M., Boudjelas S. and De Poorter M., 2000. 100 of the world's worst invasive Alien species a selection from the global invasive species database. Aliens, 12.

Mack R.N., Simberloff C.D., Lonsdale W.M., Evans H., Clout M. and Bazzaz F., 2000. Biotic invasions: Causes, Epidemiology, Global Consequences and Control. Ecology, 5, 1-24.

Maunder M.N. and Punt A.E., 2004. Standardizing catch and effort data: a review of recent approaches. Fish. Res., 70, 141-159.

Mearelli M., Giovinazzo G., Lorenzoni M., Petesse M.L. and Carosi A., 1995. Zonazione ittica dei corsi d'acqua del bacino del fiume Tevere. Atti SITE, 16, 669-671.

Meffe G.K., 1984. Effects of abiotic disturbance on coexistence of predator-prey fish species. Ecology, 65, 1525-1534.

Moran P.A.P., 1951. A mathematical theory of animal trapping. Biometrika, 38, 307-311.

ter Braak C.J.F., 1986. Canonical correspondence analysis: a new eigenvector technique for multivariate direct gradient analysis. Ecology, 67, 1167-1179.

Wege G.J. and Anderson R.O., 1978. Relative weight $\left(W_{\mathrm{r}}\right)$ : a new index of condition for largemouth bass. In: Novinger G.D. and Dillard J.G. (eds.), New approaches to the management of small impoundments, American Fisheries Society, Special Publication 5, Bethesda, Maryland, 79-91.

Zippin C., 1956. An evaluation of the removal method of estimating animal populations. Biometrics, 12, 163-189. 